\title{
New Isoniazid Complexes, Promising Agents Against Mycobacterium tuberculosis
}

\author{
Mariana Poggi, ${ }^{1}$ Rafael Barroso, ${ }^{2}$ Antonio José Costa-Filho, ${ }^{2}$ Heloisa Barbosa de Barros, ${ }^{3}$ Fernando \\ Pavan, ${ }^{3}$ Clarice Queico Leite, ${ }^{3}$ Dinorah Gambino, ${ }^{* 1}$ and María Helvecia Torre*1 \\ 1 Cátedra de Química Inorgánica, Facultad de Química, Universidad de la República, Gral Flores 2124, C. C. 1157, 11800 \\ Montevideo, Uruguay \\ 2 Faculdade de Filosofia, Ciências e Letras de Ribeirão Preto, Universidade de São Paulo, 14040-901, Ribeirão Preto (SP), \\ Brazil \\ 3 Departamento de Ciências Biológicas, Faculdade de Ciências Farmacêuticas, Universidade Estadual Paulista, UNESP, \\ Rodovia Araraquara Jaú Km, 01, 14801-902 Araraquara, SP, Brazil \\ mtorre@fq.edu.uy, dgambino@fq.edu.uy
}

Received February 27, 2013; Acepted June 5, 2013.

\begin{abstract}
Tuberculosis (TB) is a public health disease that produces several million deaths annually worldwide. Due to this critical situation and the appearance of drug-resistant microbial strains, innovation in TB drug discovery is a research priority. In this work, the synthesis and characterization by elemental analysis, thermogravimetry, conductimetric measurements and spectroscopies UV-Vis, IR and EPR of $\left[\mathrm{Cu}(\mathrm{INH})\left(\mathrm{H}_{2} \mathrm{O}\right)\right] \mathrm{SO}_{4} \cdot 2 \mathrm{H}_{2} \mathrm{O}(\mathrm{Cu}-\mathrm{INH})$ and $\left[\mathrm{CoCl}(\mathrm{INH})_{2}\left(\mathrm{H}_{2} \mathrm{O}\right)\right]$ $\mathrm{Cl} \cdot 2.5 \mathrm{H}_{2} \mathrm{O}(\mathrm{Co}-\mathrm{INH})$ complexes with isoniazid (INH) are reported. Besides, the lipophilicity, the activity against Mycobacterium tuberculosis $\left(\mathrm{MIC}_{\mathrm{Cu}-\mathrm{INH}}=0.78 \mu \mathrm{g} / \mathrm{mL}\right.$ and $\left.\mathrm{MIC}_{\mathrm{Co-INH}}=0.19 \mu \mathrm{g} / \mathrm{mL}\right)$ and the cytotoxicity $\left(\mathrm{IC}_{50}=48.8\right.$ and $625 \mu \mathrm{g} / \mathrm{mL}$ for the copper and cobalt complexes, respectively) were measured and the selectivity index (62.5 for $\mathrm{Cu}-\mathrm{INH}$ and 3205 for $\mathrm{Co}-\mathrm{INH}$ ) was calculated. These results indicate that these complexes are good candidates for further studies. Keywords: copper and cobalt complexes, isoniazid, antimycobacteria activity, tuberculosis, spectroscopy.
\end{abstract}

\section{Introduction}

Tuberculosis (TB) is a public health disease that produces several millions deaths annually worldwide [1]. In developing countries is a leading cause of mortality. Nowadays, the number of infections is growing also in developed countries, especially in immunocompromised patients such as those co-infected with human immunodeficiency virus (HIV), and in individuals receiving anti-tumour therapy or diabetics [2-4].

A big associated problem is the alarming increase of drugresistant microbial strains (MDR-TB) that makes difficult the effective control of the disease. Besides, to further complicate the matter, drug-drug interactions between TB drugs and antiHIV treatments or other chronic disease medications such as those used in diabetics are observed [2].

Due to this critical situation, innovation in TB drug discovery and evolving strategies to bring new agents with best performance is a current health priority.

One strategy to obtain new antimycobacterial drugs is the development of new molecules by reengineering old drugs with the aim to improve the antimycobacteria activity and to obtain better resistance profiles, bioavailability and tolerability, among others [3]. In particular, the coordination of metal cations with
Resumen. La tuberculosis (TB) es una enfermedad pública que produce varios millones de muertes anualmente en todo el mundo. Debido a esta crítica situación y a la aparición de cepas resistentes a los fármacos usuales, la investigación de nuevas moléculas para el tratamiento de la TB se ha vuelto una prioridad. En este trabajo se reporta la síntesis y caracterización por análisis elemental, termogravimetría, medidas conductimétricas y espectroscopías UV-Vis, IR y EPR de los complejos $\left[\mathrm{Cu}(\mathrm{INH})\left(\mathrm{H}_{2} \mathrm{O}\right)\right] \mathrm{SO}_{4} \cdot 2 \mathrm{H}_{2} \mathrm{O}(\mathrm{Cu}-\mathrm{INH})$ y $\left[\mathrm{CoCl}(\mathrm{INH})_{2}\left(\mathrm{H}_{2} \mathrm{O}\right)\right] \mathrm{Cl} \cdot 2.5$ $\mathrm{H}_{2} \mathrm{O}(\mathrm{Co}-\mathrm{INH})$ con isoniacida (INH). Por otra parte, se determinó la actividad anti-Mycobacterium tuberculosis $\left(\mathrm{CIM}_{\mathrm{Cu}-\mathrm{INH}}=0.78 \mu \mathrm{g} / \mathrm{mL}\right.$ y $\left.\mathrm{CIM}_{\mathrm{Co}-\mathrm{INH}}=0.19 \mu \mathrm{g} / \mathrm{mL}\right)$ y la citotoxicidad de los complejos $\left(\mathrm{IC}_{50}\right.$ $=48.8$ and $625 \mu \mathrm{g} / \mathrm{mL}$ respectivamente para los complejos de cobre y cobalto) y se calculó el índice de selectividad (62.5 para $\mathrm{Cu}-\mathrm{INH}$ y 3205 para Co-INH). Estos resultados indican que estos complejos son buenos candidates para continuar estudios futuros.

Palabras clave: complejos de cobre y cobalto, isoniacida, actividad antimicobacteria, tuberculosis, espectroscopía.

organic drugs is a promising strategy that has been successful in many cases with different pharmacological activities [5-7]. In particular, in the research of new antimycobacteria compounds with best activity and/or lower resistant effects, several metallic complexes were reported in the literature. For example, silver complexes with $\alpha$-hydroxycarboxilic acids have proved to be effective antimycobacterial compounds, potential candidates for antiseptic or disinfectant products [8]. On the other hand, several series of homoleptic and heteroleptic iron, copper and ruthenium compounds were developed being more active than the free ligands against Mycobacteria tuberculosis (M. tuberculosis) [9-14].

Taking into account these antecedents and as a part of our work in the research of new antimicrobial molecule [1519], in this article the development of new $\mathrm{Cu}$ (II) and $\mathrm{Co}(\mathrm{II})$ complexes with isoniazid (INH) is reported and the activity against $M$. tuberculosis is evaluated. Besides, the cytotoxicity in mammalian cells was determined and the selectivity index was calculated.

Isoniazid (Figure 1), the first effective drug discovered for the treatment of tuberculosis [20], is included in the group of the first-line antimycobacterial drugs used in prevention and treatment of tuberculosis. However, shortly after its discovery, 


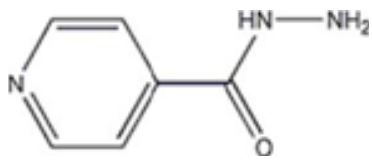

Fig. 1. Structure of isoniazid.

INH resistant $M$. tuberculosis strains were reported [21]. Although this, INH is one of the most used drugs today.

INH is able to coordinate with metal cations through different chemical groups: heterocyclic nitrogen from the pyridine ring and/or carbonylic $\mathrm{O}$ and $\mathrm{N}$ atoms of the hydrazide group. For this versatility it is also an interesting ligand from the chemical point of view.

\section{Results and discussion}

\section{Analytical results}

The elemental analyses of the complexes were:

$\left[\mathrm{Cu}(\mathrm{INH})\left(\mathrm{H}_{2} \mathrm{O}\right)\right] \mathrm{SO}_{4} \cdot 2 \mathrm{H}_{2} \mathrm{O}$ (Code $\left.\mathrm{Cu}-\mathrm{INH}\right)$, Anal $\mathrm{C}$ $21.2 \%$, N $11.9 \%$, H 3.4\%, calcd for $\mathrm{C}_{6} \mathrm{~N}_{3} \mathrm{H}_{13} \mathrm{O}_{8} \mathrm{SCu}, \mathrm{C} 21.5 \%$, $\mathrm{N} 12.0 \%$, H 3.7\%; yield: $70 \%$, $135 \mathrm{mg}$.

$\left[\mathrm{CoCl}(\mathrm{INH})_{2}\left(\mathrm{H}_{2} \mathrm{O}\right)\right] \mathrm{Cl} \cdot 2,5 \mathrm{H}_{2} \mathrm{O}$ (Code Co-INH), Anal C $31.33 \%, \mathrm{~N} 17.21 \%, \mathrm{H} 4.69 \%, \mathrm{Cl} 15.40 \%$, calcd for $\mathrm{C}_{12} \mathrm{~N}_{6} \mathrm{H}_{21} \mathrm{O}_{5.5} \mathrm{CoCl}_{2}, \mathrm{C} 30.82 \%, \mathrm{~N} 17.98 \%, \mathrm{H} 4.49 \%, \mathrm{Cl}$ $15.20 \%$; yield: $76 \%, 196 \mathrm{mg}$.

These results agree with the proposed stoichiometries.

\section{Thermogravimetric and conductimetric measurements}

Thermogravimetric results are shown in Table 1.

Experimental mass losses agree with calculated values for the two complexes.

The thermal process corresponding to $\mathrm{Cu}$-INH firstly shows the release of two hydration water molecules at $58.5^{\circ} \mathrm{C}$ while the release of the coordinated water molecule took place at $112.9^{\circ} \mathrm{C}$, as expected. The decomposition of the organic moiety starts above $140{ }^{\circ} \mathrm{C}$ forming the copper oxide at the end of calcination. Similarly, the thermogram of Co-INH indicates that the complex has 2.5 hydration water molecules and one coordinated molecule.

Results of the conductimetric measurements in dimethyl sulfoxide (DMSO) solutions are shown in Table 2.

Table 1. Thermal data for the metal-INH complexes.

\begin{tabular}{ccccc}
\hline Complex & $\begin{array}{c}\text { Temperature } \\
\text { range }\left({ }^{\circ} \mathbf{C}\right)\end{array}$ & $\begin{array}{c}\text { DrTGA } \\
\text { minima } \\
\left({ }^{\mathbf{0}} \mathbf{C}\right)\end{array}$ & $\begin{array}{c}\text { Mass } \\
\text { loss }(\%) \\
\text { Found/Calc. }\end{array}$ & $\begin{array}{c}\text { Removed } \\
\text { group }\end{array}$ \\
\hline $\mathrm{Cu}-\mathrm{INH}$ & $20-80$ & 58.5 & $10.6 / 10.3$ & $2 \mathrm{H}_{2} \mathrm{O}$ \\
& $80-140$ & 112.9 & $4.6 / 5.1$ & $\mathrm{H}_{2} \mathrm{O}$ \\
$\mathrm{Co}-\mathrm{INH}$ & $20-80$ & 40.4 & $9.2 / 9.6$ & $2.5 \mathrm{H}_{2} \mathrm{O}$ \\
& $80-130$ & 100.3 & $3.9 / 3.8$ & $\mathrm{H}_{2} \mathrm{O}$ \\
\hline
\end{tabular}

According to previous reports the conductivities obtained for both complexes are in agreement with the assigned formula for a 1:1 electrolyte type in DMSO [22-23].

In addition, the conductivity was measured in the same solutions after $48 \mathrm{hs}$ and no major changes were observed showing the stability of the complexes in DMSO.

\section{Spectroscopic measurements}

\section{Infrared spectra}

The IR spectra of the complexes were compared with those of the free ligands and previously reported complexes [24-27].

Table 3 shows the tentative assignments of the main bands of free isoniazid and the metal complexes.

Analysis of $\mathrm{Cu}$-INH spectrum

According to bibliographic reports [24, 25], the INH spectrum presents two bands at 3300 and $3209 \mathrm{~cm}^{-1}$ corresponding to asymmetric and symmetric stretching of $\mathrm{NH}_{2}$ group. Upon copper complexation the $\mathrm{v}_{\mathrm{a}}\left(\mathrm{NH}_{2}\right)$ shifted to lower frequencies while the $v_{\mathrm{s}}\left(\mathrm{NH}_{2}\right)$ was not identified due to the broad bands in the region [26]. Besides, the band assigned as $v(\mathrm{~N}-\mathrm{H})$ doesn't shift in the complex showing that this group does not participate in the coordination. On the other hand, INH spectrum shows one band at $1667 \mathrm{~cm}^{-1}$ assigned as $v(\mathrm{C}=\mathrm{O})$. In the complex

Table 2. Conductivity $(\mu \mathrm{S})$ in DMSO at $25^{\circ} \mathrm{C}$.

\begin{tabular}{cc}
\hline Complex & $\Lambda_{\text {DMSo }}(\mu \mathrm{S})$ at $\mathbf{2 5}^{\circ} \mathbf{C}$ \\
\hline $\mathrm{Cu}-\mathrm{INH}$ & 35.3 \\
$\mathrm{Co}-\mathrm{INH}$ & 52.0 \\
\hline
\end{tabular}

Table 3. Main IR bands and their assignment for $\mathrm{Cu}-\mathrm{INH}$ and $\mathrm{Co}-$ INH.

\begin{tabular}{cccc}
\hline INH & Cu-INH & Co-INH & Assignment \\
\hline- & $3409(\mathrm{br})$ & $3378(\mathrm{br})$ & $v(\mathrm{O}-\mathrm{H})_{\mathrm{water}}$ \\
$3300(\mathrm{~m})$, & $3247(\mathrm{~m}, \mathrm{br})$, & $3209(\mathrm{~s})$, & $v\left(\mathrm{NH}_{2}\right)$ \\
$3209(\mathrm{~m})$ & - & $3176(\mathrm{~s})$ & \\
$3114(\mathrm{~s})$ & $3114(\mathrm{~s})$ & $3114(\mathrm{~s})$ & $v(\mathrm{~N}-\mathrm{H})$ \\
$1667(\mathrm{vs})$ & $1655(\mathrm{vs})$ & $1650(\mathrm{vs})$ & $v(\mathrm{C}=\mathrm{O})$ \\
$1635(\mathrm{~s})$, & $1648(\mathrm{sh})$, & $1637(\mathrm{sh})$, & $v(\mathrm{C}-\mathrm{N})_{\mathrm{py}}$ \\
$1557(\mathrm{vs})$ & $1543(\mathrm{vs})$ & $1550(\mathrm{~s})$ & \\
$1492(\mathrm{~m})$ & $1498(\mathrm{~m})$ & $1500(\mathrm{~s})$ & $\delta(\mathrm{CNH})$ \\
$1334(\mathrm{~s})$ & $1370(\mathrm{~m})$ & $1333(\mathrm{~m})$ & $v(\mathrm{C}-\mathrm{N})_{\mathrm{amide}}$ \\
$1142(\mathrm{~s})$ & $1148(\mathrm{~s})$ & $1140(\mathrm{~m})$ & $v(\mathrm{~N}-\mathrm{N})$ \\
$888(\mathrm{~m})$ & $864(\mathrm{~m})$ & $898(\mathrm{~m})$ & $\delta(\mathrm{C}-\mathrm{N}-\mathrm{C})_{\mathrm{py}}$ \\
$504(\mathrm{~m})$ & $570(\mathrm{~m})$ & $535(\mathrm{~m})$ & $\delta(\mathrm{C}-\mathrm{C}-\mathrm{C})_{\mathrm{py}}$ \\
- & $1118(\mathrm{~s})$ & - & $v(\mathrm{~S}-\mathrm{O})$ \\
- & $610(\mathrm{~s})$ & - & $\delta(\mathrm{S}-\mathrm{O})$ \\
- & $281(\mathrm{w})$ & $279(\mathrm{~m})$ & $v(\mathrm{M}-\mathrm{N})$ \\
\hline br = strong, vs $=$ broad. & & &
\end{tabular}


this band shifted to $1655 \mathrm{~cm}^{-1}$ remarking the copper coordination through this group. Similar shifts were observed in complexes where the metal coordinate through the $-\mathrm{C}=\mathrm{O}$ group $[27,28]$. This behavior permits to propose that INH acts as a bidentate ligand coordinating through the $-\mathrm{NH}_{2}$ and the $\mathrm{C}=\mathrm{O}$ groups.

Regarding the $v(\mathrm{C}-\mathrm{N})_{\text {amide }}$ and $v(\mathrm{~N}-\mathrm{N})$ bands the coordination affects only the first one. A plausible explanation would be that the coordination through the $\mathrm{C}=\mathrm{O}$ group weakens the $\mathrm{C}-\mathrm{O}$ bond and consequently reinforces the $\mathrm{N}-\mathrm{H}$ one, shifting the $v(\mathrm{C}-\mathrm{N})_{\text {amide }}$ to a higher frequency.

Upon complex formation, the shifts of pyridine vibrations in the high-frequency region usually are small, whereas those corresponding to bendings are more evident and shifted to higher frequencies [26]. As Table 3 shows, in the high-frequency region the band corresponding to $v_{\mathrm{a}}(\mathrm{C}-\mathrm{N})_{\mathrm{py}}\left(1635 \mathrm{~cm}^{-1}\right)$, $v_{\mathrm{s}}(\mathrm{C}-\mathrm{N})_{\mathrm{py}}\left(1557 \mathrm{~cm}^{-1}\right)$ and $\delta(\mathrm{C}-\mathrm{N}-\mathrm{C})_{\mathrm{py}}\left(888 \mathrm{~cm}^{-1}\right)$ show minor shifts $\left(13-24 \mathrm{~cm}^{-1}\right)$ to higher or lower frequencies. On the contrary, the low-frequency region evidences more clearly the coordination through the heterocyclic nitrogen atom. Especially the band at $504 \mathrm{~cm}^{-1}$ assigned as a ring C-C-C bending [29] shifted to $570 \mathrm{~cm}^{-1}$, confirming the coordination through pyridine. Due to the fact that the aromatic pyridine ring is rigid, the coordination through the heterocyclic $\mathrm{N}$ atom should be given with another copper ion different than that coordinated with the hydroxamine group, in a dimeric or polymeric structure.

Regarding the metal-ligand bands, only one band was observed at $281 \mathrm{~cm}^{-1}$ and it was assigned as $v(\mathrm{Cu}-\mathrm{O})$ taking into account previous work [26, 29].

The inorganic sulfates present only one stretching band usually found in the range $1140-1080 \mathrm{~cm}^{-1}$. Besides, sulfate bonds can bend giving rise to one or two bands in the 680-610 $\mathrm{cm}^{-1}$ range, sharper than the stretching bands [26]. In the case of $\mathrm{Cu}-\mathrm{INH}$ the bands at 1118 and $610 \mathrm{~cm}^{-1}$ confirm the presence of a sulfate counterion.

Besides, the broad band at $3409 \mathrm{~cm}^{-1}$ confirms the presence of water molecules in the complex.

\section{Analysis of the Co-INH spectrum}

The Co-INH spectrum shows the shifts of $v_{\mathrm{a}}\left(\mathrm{NH}_{2}\right)$ and $v_{\mathrm{s}}\left(\mathrm{NH}_{2}\right)$ to lower frequencies (see Table 3 ), according to the cobalt coordination through this group [26]. Besides, the $v(\mathrm{C}=\mathrm{O})$ shifts to lower frequencies in a similar behavior to that observed in $\mathrm{Cu}-\mathrm{INH}$ spectrum. The $v(\mathrm{~N}-\mathrm{H})$ does not change in the complex showing that this group does not participate in the coordination. Taking into account this analysis, we can propose that isoniazid acts as a bidentate ligand.

Unlike the case of the $\mathrm{Cu}-\mathrm{INH}$, in the Co-INH spectrum no significant changes in the pyridine vibrations were observed. This would discard the coordination through the heterocyclic nitrogen atom.

On the other hand, only one band was observed at $279 \mathrm{~cm}^{-1}$ and it was assigned as $v(\mathrm{Co}-\mathrm{O})$ taking into account previous reports [26, 29].

Besides, the broad band at $3378 \mathrm{~cm}^{-1}$ confirms the presence of water molecules in the complex.

\section{Electronic spectra}

Copper(II) complexes of lower coordination number can exist in a wide range of stereochemistries, some of them distorted, making it difficult to use electronic spectroscopy for identifying structures [30]. In the case of $\mathrm{Cu}-\mathrm{INH}$, the electronic spectrum in a nujol suspension shows one poorly defined broad band at $600 \mathrm{~nm}$ almost overlapped by ligand bands. This result agrees with the report of similar complexes with a $\mathrm{CuN}_{2} \mathrm{O}_{2}$ chromophore [30].

On the other hand, the Co-INH is a pale pink powder, typically of octahedral complexes [31]. It is known that high spin six coordinate cobalt(II) complexes generally show, in a visible region, a multiple structured band assigned to ${ }^{4} \mathrm{~T}_{1 \mathrm{~g}}(\mathrm{~F})$ $\rightarrow{ }^{4} \mathrm{~T}_{1 \mathrm{~g}}(\mathrm{P})$ [30]. In the reflectance spectrum of Co-INH three bands at 606,695 and $725 \mathrm{~nm}$, and a shoulder at $668 \mathrm{~nm}$ are observed.

\section{EPR spectra}

The EPR spectrum of a polycrystalline sample of $\mathrm{Cu}-\mathrm{INH}$ at $\mathrm{X}$-band is shown in Figure 2.

This spectrum shows two main resonances centered around 290 and $325 \mathrm{mT}$ and that are attributed to transitions allowed by the interaction between the magnetic moment of the unpaired electron and the spectrometer magnetic field (Zeeman interaction). Those two resonances are characteristic of an axially symmetric paramagnetic center with principal components of the g-tensor given by $\mathrm{g}_{\perp}=2.023$ and $\mathrm{g}_{/ /}=2.236$ as calculated directly from the resonance positions (in units of magnetic field) and from the frequency of microwave radiation used in the experiment. The relation $\mathrm{g}_{/ /}>\mathrm{g}_{\perp}$ indicates that the unpaired electron is in $\mathrm{a} \mathrm{d}_{\mathrm{x}-\mathrm{y}}{ }^{2}$ ground state orbital. Copper ions have nuclear spin of $3 / 2$ that would give rise to extra resonance lines in their spectrum (hyperfine interaction). However, no such lines are observed in Figure 2, which is a situation usually found in the cases where copper - copper interactions are observed [32-36].

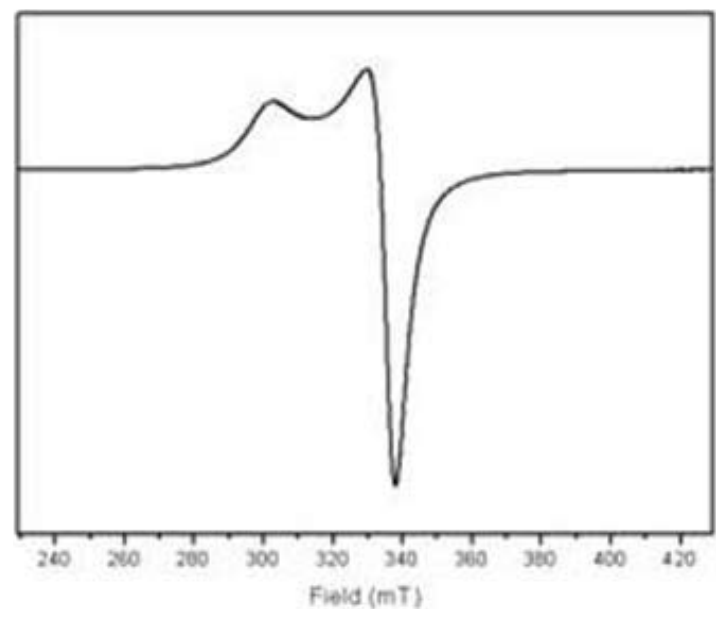

Fig. 2. X-band EPR spectrum of a polycrystalline sample of $\mathrm{Cu}$ INH. 
It is also worth noting the absence of extra resonances for both low (below $275 \mathrm{mT}$ ) and high (above $375 \mathrm{mT}$ ) fields and also of the so-called half-field transition, which is typical of copper pairs [37]. Together these features suggest that the copper ions in $\mathrm{Cu}-\mathrm{INH}$ are arranged as a polymeric structure in the solid state, as shown in Figure 3.

As a result of the experimental analytical data and the spectroscopic studies (IR, UV-Vis and EPR) the proposed structures for the complexes are shown in Figure 3.

\section{Lipophilicity and solubility}

Before the study of lipophilicity, the stability of complexes in physiological solution was determined. A thin-layer chromatography using the experimental conditions presented in 3.4 was performed. The solutions analyzed were: saturated solution of $\mathrm{Cu}-\mathrm{INH}$ in physiological serum, saturated solution of $\mathrm{Cu}-$ INH in water, saturated solution of Co-INH in physiological serum and saturated solution of Co-INH in water. After the experiment, only one spot was observed in each Co-INH chromatogram and the $\mathrm{R}_{\mathrm{f}}$ were 0.73 in both solutions, showing that the presence of $\mathrm{Cl}^{-}$does not affect the species in the physiological solution. The same behavior was observed in the case of $\mathrm{Cu}-\mathrm{INH}$ but the $\mathrm{R}_{\mathrm{f}}$ was almost 0 according to the low solubility of the complex in methanol.

With the aim to determine the lipophilic character of the complexes that can be correlated with biological properties like the passage through lipophilic barriers, distribution coefficients (D) between n-octanol and physiological solutions were determined. Besides, the solubility in water and DMSO was estimated. These results are presented in Table 4.

The $\mathrm{D}$ values obtained for the complexes are higher than that of the free ligand. According to the results shown in Table 4 , the compound most soluble in water (isoniazid) was the less lipophilic while both complexes presented lower solubility and were more lipophilic than isoniazid, as expected.

The solubilities in DMSO are higher than the values obtained in aqueous solution. For this reason this solvent was used in the microbiological assays.
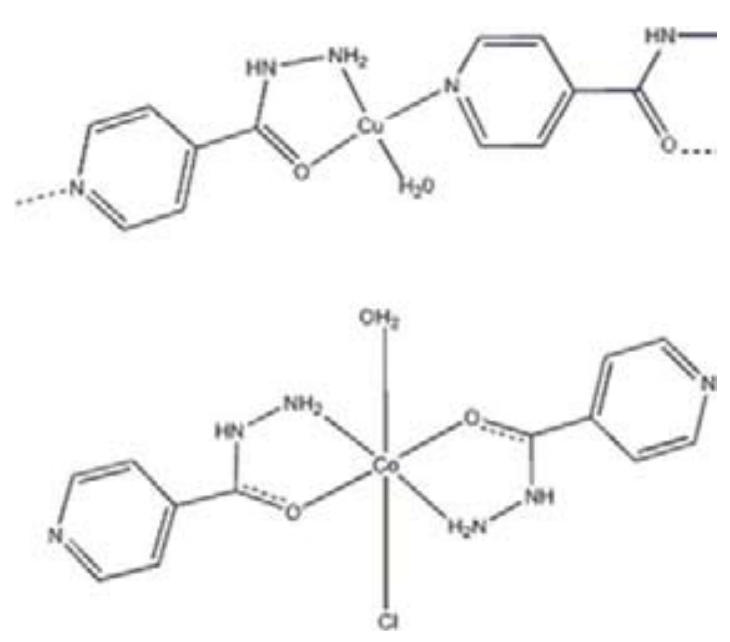

Fig. 3. Proposed structures for $\mathrm{Cu}-\mathrm{INH}(\mathrm{A})$ and $\mathrm{Co}(\mathrm{INH})(\mathrm{B})$.
Anti-M. tuberculosis activity and cytotoxicity on mammalian cells

The minimum inhibitory concentration (MIC) values against M. tuberculosis, the $\mathrm{IC}_{50}$ and the selectivity index of the metalINH complexes and the free ligand are presented in Table 5. None of the metallic salt dilutions $\left(\mathrm{CuSO}_{4}\right.$ and $\left.\mathrm{CoCl}_{2}\right)$, used as control, inhibited the growth of mycobacterium. In the case of $\mathrm{Cu}-\mathrm{INH}$, the molecular weight of the monomeric complex was used to calculate the MIC, due to the uncertainty in knowing the molecular weight in solution. If polymeric structures exist in solution the calculated MIC values expressed in $\mu \mathrm{M}$ will be lower.

As table 5 shows, both complexes were active against $M$. tuberculosis. The MIC values are lower than that of the ethambutol $(\mathrm{MIC}=5.62 \mu \mathrm{g} / \mathrm{mL}, 27.5 \mu \mathrm{M})$ and p-aminosalicylic $(\mathrm{MIC}=1.25 \mu \mathrm{g} / \mathrm{mL}, 8.16 \mu \mathrm{M})$, antimycobacterial agents in clinical use.

Besides, $\mathrm{Cu}-\mathrm{INH}$ complex $(\mathrm{MIC}=2.2 \mu \mathrm{M})$ is less active than isoniazid $(\mathrm{MIC}=0.063 \mu \mathrm{g} / \mathrm{mL}, 0.46 \mu \mathrm{M})$ while $\mathrm{Co}-\mathrm{INH}$ $(\mathrm{MIC}=0.41 \mu \mathrm{M})$ has similar activity but both complexes presented MIC values well below $25 \mu \mathrm{g} / \mathrm{mL}$, considered as a limit to continue the anti-mycobacterial studies, according to pipeline by Pavan et al. [38].

One thing to note is that Co-INH was more active than $\mathrm{Cu}-\mathrm{INH}$ and more lipophilic. However, isoniazid was less lipophilic than the complexes but it was the most active one. INH is a prodrug which is active after transformation, by a peroxidase, to isonicotinic acid that inhibits the synthesis of the mycolic acid required for the biosynthesis of mycobacterial cell wall [9]. INH enters into the cell by passive transportation [39] [40]. In spite of its polarity this molecule is a very powerful drug. In the case of our complexes, two mechanisms would be possible:

Table 4. Distribution coefficients (D) between n-octanol and physiological solutions, and estimated solubility (S) of the complexes.

\begin{tabular}{cccc}
\hline Complex & D/ logD* & $\begin{array}{c}\text { S (mg/100 } \mathbf{~ m L} \\
\text { water })\end{array}$ & $\begin{array}{c}\text { S (mg/100 } \mathbf{~ m L} \\
\text { DMSO) }\end{array}$ \\
\hline INH & $0.07 /-1.2$ & 1667 & 815 \\
$\mathrm{Cu}-\mathrm{INH}$ & $0.16 /-0.79^{* *}$ & 3.0 & 5.8 \\
$\mathrm{Co}-\mathrm{INH}$ & $0.33 /-0.48^{* *}$ & 75 & 150 \\
\hline
\end{tabular}

* strength force $=0.15 \mathrm{M}, 25^{\circ} \mathrm{C}$.

** $\mathrm{pH}=4.98$ (for $\mathrm{Cu}-\mathrm{INH}$ ) and 4.38 (for $\mathrm{Co}-\mathrm{INH}$ ).

Table 5. MIC (mg/mL), $\mathrm{IC}_{50}$ and Selectivity Index for $\mathrm{Cu}-\mathrm{INH}$, CoINH.

\begin{tabular}{llllll}
\hline Compound & $\begin{array}{l}\mathbf{M I C}^{*} \\
(\mu \mathbf{g} / \mathbf{m L})\end{array}$ & $\begin{array}{l}\mathbf{M I C}^{*} \\
(\mu \mathrm{M})\end{array}$ & $\mathbf{I C}_{\mathbf{5 0}}(\boldsymbol{\mu g} / \mathbf{m L}) / \mathbf{I C}_{\mathbf{5 0}}(\boldsymbol{\mu M})$ & SI** $^{*}$ & \\
\cline { 2 - 6 } & & & VERO & $\mathbf{J 7 7 4 A . 1}$ & \\
\hline $\mathrm{Cu}-\mathrm{INH}$ & 0.78 & 2.2 & $62.5 / 178$ & $58.6 / 167$ & 80.1 \\
$\mathrm{Co}-\mathrm{INH}$ & 0.19 & 0.41 & $>500 / 1070$ & $>500 / 1070$ & 2631.6 \\
\hline
\end{tabular}

* The obtained MIC values were the same in the triplicate assays **The selectivity index (SI) was calculated by the ratio between VERO/MIC. 
the complexes would pass through the cell wall by a different mechanism than isoniazid or they would act through a different mechanism of action. Due to the fact that the mode of action of isoniazid requires the biotransformation to isonicotinic acid, the stable coordination to a metal center would block the whole process leading to an inactivation of isoniazid. In our case, both new metal complexes are active allowing to conclude that the mode of action of the complexes could be completely different to that of free isoniazid. If this hypothesis could be verified through further studies these compounds would be good drug candidates.

Another interesting aspect of these complexes is the cytotoxicity shown on two different mammalian cells lineages. The models chosen were the VERO (ATCC CCL81) and J774.A1 (ATCC TIB-67) cells. VERO cells are considered normal cells and do not represent any disease. These cells are largely used as phenotypic screening in drug discovery in response of the cytotoxicity of the compounds. J774A.1 are macrophage cells, that represent the first ones of the immunological response. Also, mycobacteria has the ability to survive inside them. All the complexes showed moderate cytotoxicity on these cell lines and good selectivity indexes (Table 5).

As a conclusion, the synthesis and characterization of two new isoniazid complexes are reported. According to the spectroscopic analysis the copper complex presents a polymeric structure where the isoniazid acts as a bridge between two different copper ions, coordinating through the heterocyclic nitrogen, the amine and carbonyl groups.

The cobalt complex presents an octahedral geometry where the isoniazid is a bidentate ligand. These two examples show the versatility of isoniazid as ligand.

Both complexes were active against $M$. tuberculosis showed MIC values well below $25 \mu \mathrm{g} / \mathrm{mL}$ considered as a limit to continue the antimycobacterium studies. Besides, they showed low cytotoxicity on different mammalian cell lines and consequently they presented high selectivity indexes.

Due to these results, $\mathrm{Cu}-\mathrm{INH}$ and Co-INH are interesting candidates for further studies.

\section{Experimental}

All starting materials were commercially available researchgrade chemicals and were used without further purification.

\section{Synthesis}

The copper and cobalt complexes were synthesized mixing aqueous solutions of $\mathrm{CuSO}_{4} \cdot 5 \mathrm{H}_{2} \mathrm{O}(0.55 \mathrm{mmol}, 137 \mathrm{mg})$ or $\mathrm{CoCl}_{2} \cdot 6 \mathrm{H}_{2} \mathrm{O}(0.55 \mathrm{mmol}, 130 \mathrm{mg})$ and isoniazid $(1.10 \mathrm{mmol}$, $150 \mathrm{mg}$ ) with continuous stirring for $30 \mathrm{~min}$. The resulting green or pink precipitates corresponding to copper or cobalt complexes respectively were filtered, washed with small portions of water and dried at room temperature.

The elemental analysis was performed with a Carlo Erba EA1108 elemental analyser. Sulphate was identified by pre- cipitation with $\mathrm{BaCl}_{2}$ and chloride was quantified through a potentiometric method using $\mathrm{AgNO}_{3}$.

\section{Thermogravimetric and conductimetric measurements}

Thermogravimetric measurements were performed with a Shimadzu TGA 50 thermobalance, with a platinum cell, working under flowing air $\left(50 \mathrm{~mL} \mathrm{~min}^{-1}\right)$ and at a heating rate of 0.5 ${ }^{\circ} \mathrm{C}$ min $^{-1}$ until $80{ }^{\circ} \mathrm{C}$ and $1{ }^{\circ} \mathrm{C} \mathrm{min}-1$ above $80{ }^{\circ} \mathrm{C}$.

Conductimetric measurements using a Conductivity Meter 4310 Jenway were performed at $25^{\circ} \mathrm{C}$ in a DMSO solution $\left(10^{-4} \mathrm{M}\right)$, solvent used in the microbiological assays. The stability of the complexes in this solvent was followed by measuring conductivity of these solutions for $48 \mathrm{~h}$ of the dissolution and compared with the initial conductivity.

\section{Spectroscopic measurements}

IR spectra, in the range between 4000 and $200 \mathrm{~cm}^{-1}$, were recorded on a Bomem M 102 FTIR spectrophotometer using the $\mathrm{KBr}$ pellet technique.

Electronic spectra of complexes in a Nujol suspension were registered on a Shimadzu UV-1603 spectrophotometer.

Room temperature EPR measurements of the copper complex were carried out on polycrystalline samples using a JEOL JES-FA200 spectrometer. The experimental parameters were: microwave frequency, $9.4 \mathrm{GHz}$; microwave power, $10 \mathrm{~mW}$; field modulation,

EPR measurements of the copper complex were carried out on polycrystalline samples using an X-band Varian E109 spectrometer. The experimental parameters were microwave frequency: $9.4 \mathrm{GHz}$, microwave power: $10 \mathrm{~mW}$, field modulation: $100 \mathrm{kHz}$, modulation amplitude: $0.2 \mathrm{mT}$, time constant: $0.03 \mathrm{~s}$, scan time: $2 \mathrm{~min}$. The parameters were optimized to avoid saturation and/or distortions

\section{Thin-layer chromatography}

With the aim of studying the stability of complexes in physiological solution and in water, a thin-layer chromatography was performed with a saturated solution of complexes in both solvents. A silica gel G, $250 \mu \mathrm{m}$ plate and a $\mathrm{CH}_{3} \mathrm{OH}: \mathrm{NH}_{3}$ (100:1.5) solution as a mobile phase were used. $10 \mu \mathrm{L}$ of each solution (saturated solution of $\mathrm{Cu}-\mathrm{INH}$ and $\mathrm{Co}-\mathrm{INH}$ in physiological solution, and saturated solutions of $\mathrm{Cu}-\mathrm{INH}$ and Co-INH in water) were seeded in the plate. After the chromatography, the spots were detected with UV lamp [41].

\section{Lipophilicity test and solubility}

Lipophilicity tests at $25{ }^{\circ} \mathrm{C}$ were performed determining the partition coefficient $(\mathrm{P})$ between $\mathrm{n}$-octanol and physiological solution [42]. The concentration of the compounds in the physiological solution before and after the contact with n-octanol was determined by UV spectroscopy at $260 \mathrm{~nm}$. This isoniazid band does not shift with complexation. 
The solubility at $37{ }^{\circ} \mathrm{C}$ in water and DMSO was also estimated.

\section{Anti-M. tuberculosis activity}

The anti-MTB activity of the compounds was determined by the REMA (Resazurin Microtiter Assay) method according to Palomino et al, 2002 [43]. Stock solutions of the tested compounds were prepared in dimethyl sulfoxide (DMSO) and diluted in Middlebrook 7H9 broth (Difco) supplemented with oleic acid, albumin, dextrose and catalase (OADC enrichment - BBL/Becton-Dickinson), to obtain final drug concentration ranges of $0.09-25 \mu \mathrm{g} / \mathrm{mL}$. The isoniazid was dissolved in distilled water, and used as standard drug. A suspension of the MTB $\mathrm{H}_{37} \mathrm{Rv}$ ATCC 27294 was cultured in Middlebrook 7H9 broth supplemented with OADC and $0.05 \%$ Tween 80 . The culture was frozen at $-80^{\circ} \mathrm{C}$ in aliquots. After two days was carried out the $\mathrm{CFU} / \mathrm{mL}$ of a aliquot. The concentration was adjusted by $5 \times 10^{5} \mathrm{CFU} / \mathrm{mL}$ and $100 \mu \mathrm{L}$ of the inoculum was added to each well of a 96-well microplate together with $100 \mu \mathrm{L}$ of the compounds. Samples were set up in triplicate. The plate was incubated for 7 days at $37{ }^{\circ} \mathrm{C}$. After $24 \mathrm{~h}, 30 \mu \mathrm{L}$ of $0.01 \%$ resazurin (solubilized in water) was added. The fluorescence of the wells was read after $24 \mathrm{~h}$ in a TECAN Spectrafluor ${ }^{\circledR}$. The MIC was defined as the lowest concentration resulting in $90 \%$ inhibition of growth of MTB.

\section{Cytotoxicity on mammalian cells}

In vitro cytotoxicity assays $\left(\mathrm{IC}_{50}\right)$ were performed first on the VERO epithelial cells (ATCC CCL81). Compounds with low cytotoxicity were investigated on the J774A.1 (ATCC TIB-67) mouse cell line. Both studies as recommended by Pavan et al. 2010 [44]. The cells were routinely maintained in complete medium (DMEM for VERO and RPMI-1640 (VitroCell ${ }^{\circledR}$ ) for J774A.1) supplemented with $10 \%$ heat-inactivated fetal bovine serum (FBS) plus gentamicin $(50 \mathrm{mg} / \mathrm{L})$ and anfotericin B (2 $\mathrm{mg} / \mathrm{L})$, at $37{ }^{\circ} \mathrm{C}$, in a humidified $5 \% \mathrm{CO}_{2}$ atmosphere. After reaching confluence, the cells were detached and counted. For the cytotoxicity assay, $1 \times 10^{5}$ cells $/ \mathrm{mL}$ were seeded in $200 \mu \mathrm{L}$ of complete medium in 96-well plates (NUNC ${ }^{\mathrm{tm}}$ ). The plates were incubated at same conditions for $24 \mathrm{~h}$, to allow cell adhesion prior to drug testing. The compounds were dissolved in DMSO (5\%) and subjected to two-fold serial dilution from 1250 to $3.9 \mu \mathrm{g} / \mathrm{mL}$. Cells were exposed to the compounds at various concentrations for $24 \mathrm{~h}$. Resazurin solution was then added to the cell cultures and incubated for $6 \mathrm{~h}$. Cell respiration, as an indicator of cell viability was detected by reduction of resazurin to resorufin, whose pink colour and fluorescence indicates cell viability. A persistent blue colour of resazurin is a sign of cell death. The fluorescence measurements $(530 \mathrm{~nm}$ excitation filter and $590 \mathrm{~nm}$ emission filter) were performed in a Tecan Spectrafluor Plus microfluorimeter. $\mathrm{The} \mathrm{IC}_{50}$ value was defined as the highest drug concentration at which $50 \%$ of the cells are viable relative to the control. Each test was set up in triplicate.

\section{Selectivity Index}

The selectivity index (SI) was calculated by dividing $\mathrm{IC}_{50}$ for the VERO cells by the MIC for the pathogen; if the SI is $\geq 10$, the compound is then investigated further.

\section{Acknowledgements}

The authors thank CYTED network (209RT0380), FAPESP (process. 2009/06499-1 and 2011/11593-7), ANII for the scholarship of Mariana Poggi (BE_INI_2010_1851) and Dr. Jorge Castiglioni for the collaboration on the thermogravimetric assays.

\section{References}

1. World Health Organization, Global Tuberculosis Report 2012, 2012, 3 .

2. Koul, A.; Arnoult, E., Lounis, N.;Guillemont, J.; Andries, K. Nature 2011, 469, 483-490.

3. Wolff, M.E., Burger's Medicinal Chemistry and Drug Discovery, Vol. 2. John Wiley \& Sons. Laguna Beach, 1996.

4. Sweetman, S.C., Martindale. Guía completa de consulta farmacoterapéutica, Pharma Editores. Barcelona, 2008.

5. Gambino, D.; Otero, L. Inorg. Chim. Acta 2012, 393, 103-114.

6. Ruiz-Azuara, L.; Bravo-Gómez, M.E. Curr. Med. Chem. 2010, 17, 3606-3615.

7. Ballin, J.C. JAMA, 1974, 230, 8, 1184-1185.

8. Cuin, A.; Massabni, A.C.; Leite, C.Q.; Sato, D.N.; Neves, A.; Szpoganicz, B.; Silva, M.S.; Bortoluzzi, A. J. J. Inorg. Biochem. 2007, 101, 291-296.

9. Oliveira, J. S.; Douza, E. H.S.; Basso, L.A.; Palaci, M.; Dietze, R.; Santos, D. S.; Moreira, I.S. Chem. Commun. 2004, 312-313.

10. Sousa, E.H.S.; Pontes, D.L.; Diógenes, I.C.N.; Lopes, L.G.F.; Oliveira, J.S.; Basso, L.A.; Santos, D. S.; Moreira, I.S. J. Inorg. Biochem. 2005, 99, 368-375.

11. Oliveira, J. S.; Sousa, E. H. S.; Basso, L. A.; Palaci, M.; Dietze , R.; Santos, D. S.; Moreira, Ícaro S. Chem. Commun.2004, 3, 312313.

12. Pavan, F. R.; Poelhsitz, G.V.; Barbosa, M. I. F.; Leite, S. R. A.; Batista, A. A.; Ellena, J.; Sato, L. S.; Franzblau, S.G.; Moreno, V.; Gambino, D.; Leite, C. Q. F. Eur. J. Med. Chem.2011, 46, 10, 5099-5107.

13. Maccari, R.; Ottanà, R.;Bottari, B.; Rotondo, E.; Vigorita, M.G. Bioorg. Med. Chem. Letters, 2004, 14, 23, 5731-5733.

14. Carmo, A.M.L.; Silva, F.M. C.; Machado, P. A.; Fontes, A.P.S.; Pavan, F. R.; Leite, C.Q.F.; Leite, S. R. De A.; Coimbra, E.S.; Da Silva, A.D. Biom. Pharm. 2011, 65, 3, 204-209.

15. Tarallo; M.B.; Urquiola, C; Monge Vega, A.; Parajón Costa, B.; Ribeiro, R. R.;Costa-Filho, A.J.; Mercader, R.C.; Pavan, F.; Leite, C.Q.; Torre, M.H.; Gambino, D. J. Inorg. Biochem. 2010, 104, 11, 1164-1170.

16. Tarallo; M.B.; Costa-Filho, A.J.;Viera, E.; Monge Vega, A.;Leite, C.Q.; Pavan, F.; Borthagaray, G.; Gambino, D.; Torre, M.H. J. Argent. Chem. Soc. 2009, 97, 1, 80-89.

17. Mondelli, M; Pavan, F.; De Souza; Leite, C.Q.; Ellena, J.; Nascimento, O.R.; Facchin, G.; Torre, M.H. J. Mol. Struct.2012, 1036, 180-187.

18. Mondelli, M;Bruné V.; Borthagaray, G.; Ellena, J.; Nascimento, O.R.; Leite, C.Q.; Batista, A.A.; Torre, M.H. J. Inorg. Biochem. 2008, 102, 285-292. 
19. Kremer, E; Facchin, G; Estévez, E.;Alborés P.;Baran, E.J.;Ellena; Torre, M.T. J. Inorg. Biochem. 2006, 100, 1167-1175.

20. Bernstein, J.;Lott, W.A.; Steinberg, B.S.; Yale, H.L. Am. Rev. Tuberc.1952, 65, 357-364.

21. Middlebrook, G. Am. Rev. Tuberc.1952, 65, 765-767.

22. Geary, W.J. Coord. Chem. Rev.1971, 7, 81-122.

23. Broomhead, J.A.; Kane-Maguire, L.A.P. J. Chem. Soc. A, 1967, 546-553.

24. Lin-Vien, D.; Colthup, N.B.; Fateley, W.G.; Grasselli, J.G. The Handbook of Infrared and Raman Characteristic Frequencies of Organic Molecules, Academic Press inc., Boston, 1991.

25. Gunasekaran, S.; Sailatha,E.;Seshadri, S.;Kumaresan, S. Indian J. Pure Ap. Phy. 2009, 47, 12-18.

26. Nakamoto, K. Infrared and Raman Spectra of Inorganic and Coordination Compounds. Part B. 5, John Wiley and Sons, New York, 1997.

27. Tang, X.; Dou, W.; Chen, S.; Dang, F.; Liu, W. Spectrochim. Acta Part A. 2007, 68, 349-353.

28. Nelwamondoa, A. N.;Eveb, D. J.; Watkinsb, G. M.;Brown, M. E. Thermochim. Acta. 1998, 318, 165-175.

29. Smith, B. Infrared Spectral Interpretation. A Systemic Approach, CRS Press, Boca Ratón, 1998.

30. Lever, A.B.P., Inorganic Electronic Spectroscopy, Elsevier, New York, 1984.

31. Cotton, F. A.; Wilkinson, G.; Murillo, C.A.; Bochmenn, M., Advanced Inorganic Chemistry, 6th Ed., Wiley \& sons, New York, 1999.

32. Viera, I.; Gomez, M.A.; Ellena, J.; Costa-Filho, A.J.;Migliaro, E.R.; Dominguez, L.; Torre, M.H. Polyhedron. 2009, 28, 36473653 .
33. Facchin, G.; Kremer, E.; Barrios, D.; Etcheverry, S.A.;Costa-Filho, A.J.; Torre, M.H. Polyhedron. 2009, 28, 2329-2334.

34. Das, K.; Sinha, C.; Datta, A.; Garribba, E.; Fondo, M.; Mautner, F.A. ; Fischer, R.C. J. Chem. Res.2012, 36, 12, 722-725.

35. Sanmartin, J.; Bermejo, M.R.; Garcia-Deibe, A.M. Inorg. Chim. Acta. 2001, 318, 1-2, 135-142.

36. Urquiola, C.; Gambino, D.; Cabrera, M.; Lavaggi, M.L.;Cerecetto, H.; Gonzalez, M.; Lopez de Cerain, A.; Monge Vega, A.; CostaFilho, A.J.; Torre, M.H. J. Inorg. Biochem. 2008, 102, 1, 119126.

37. Bencini, A.;Gatteschi, D., Electron Paramagnetic Resonance of Exchange Coupled Systems, Springer-Verlag, Berlin, 1990.

38. Pavan, F. R.; Sato, D. N.; Leite, C. Q. F. An approach to the search for new drugs against tuberculosis. In: Cardona, P.J. (Ed.). Mycobacterium tuberculosis, book 2. Intech, 2011.

39. Bardou, F.; Raynaud, C.; Ramos, C.; Laneelle, M.A,; Laneelle, G. Microbiology. 1998, 144, 2539-2544.

40. Scior, T.; Garcés-Eisele, S.J. Curr. Med. Chem. 2006, 13, $2205-$ 2219.

41. Poole C.F. Thin-layer Chromatography. In: Moffat, A.C.; Osselton, M.D.; Widdop, B.; Watts, J.(Eds.). Clarke's Analysis of Drugs and Poisons, Pharmaceutical Press, 2011.

42. Leo, A.; Hansch, C. D.; Elkins, J. Chem. Soc. 1971, 71, 525616.

43. Palomino, J.C.; Martin, A., Camacho, M.; Guerra, H.; Swings, J.; Portaela, F. Antimicrob. Agents Chemother. 2002, 46, 27202722.

44. Pavan, F.R.; Maia, P.I.S.; Leite, S.R.A.; Deflon, V.M.; Batista, A.A.; Sato, D.N.; Franzblau, S.G.; Leite, C.Q.F. Eur. J. Med. Chem. 2010, 45, 1898-1905. 